\title{
The role of the Bundestag in shaping the European policy of reunited Germany ${ }^{1}$
}

Following the reunification of Germany, the first parliamentary elections attended by the citizens of the former German Democratic Republic were held on December 2, 1990. However, this did not lead to any major shifts in the German political scene and power remained in the hands of the CDU/CSU-FDP coalition and Chancellor Helmut Kohl. Although the circumstances had changed, Germany's European policy continued as before and the previous role of the parliament in shaping the state's foreign policy was maintained. Members of the German Bundestag and representatives of the Federal Council (Bundesrat) exercise parliamentary control over the government's European policy, and the government should take their demands into account in its activities in the European Union. This requirement is set forth in Article 23 of the German Constitution, reading as follows: "The Bundestag and, through the Bundesrat, the Länder [represented by the Federal Council] shall participate in matters concerning the European Union. The Federal Government shall keep the Bundestag and the Bundesrat informed, comprehensively and at the earliest possible time" (Paragraph 2). "Before participating in legislative acts of the European Union, the Federal Government shall provide the Bundestag with an opportunity to state its position. The Federal Government shall take the position of the Bundestag into account during the negotiations" (Paragraph 3) (Ustawa Zasadnicza, 2007, p. 99). ${ }^{2}$ In addition, the Lisbon Treaty gave more power to national parliaments by authorizing them to verify the principle of subsidiarity, to participate in treaty amendment procedures, to build "the area of freedom, security and justice" of the EU and to access information and draft legal acts of the EU institutions (Article 8c., Traktat z Lizbony, 2009).

In Germany, it has become customary for the Chancellor to present the government's position and German postulates to the Bundestag, usually before the more important meetings of the European Council. The Chancellor's presentation is then discussed by the MPs and, after a vote, the Chancellor goes to Brussels with the position thus adopted (or modified). In this way, the public is kept informed of the government's decisions on European affairs, as parliamentary sessions are broadcast live by the state television.

The first serious problems with the European policy of reunited Germany could already be observed in the Bundestag after the signing of the Maastricht Treaty, one of

${ }^{1}$ Paper written within an NCN research grant "The role of Germany in the European Union's decision-making processes in the 21st century." UMO-2014/15/B/HS5/00723.

${ }^{2}$ For more information about the role of the Bundesrat and the Länder in formulating this policy, see Suszycka-Jasch and Jasch, The participation of the German Länder in formulating German EUpolicy, "German Law Journal” 2009, vol. 10, pp. 1215-1256. 
the milestones of European integration. The Treaty establishing the European Union, signed on February 7, 1992, required ratification by the European Parliament and the member states, either through a parliamentary path or, as in the case of France or Denmark, through a referendum. Germany, in the absence of any profound social divisions on European issues, opted for a parliamentary solution. Consequently, on December 2, 1992 the Bundestag adopted the Maastricht Treaty without much discussion and by an overwhelming majority of 543 votes in its favor, 17 votes against it, and 8 votes abstaining. The Bundesrat gave its acceptance on December 18, 1992, with all the Länder voting for the Treaty. Later that month, however, five complaints were quite unexpectedly submitted to the Federal Constitutional Court in Karlsruhe, challenging the ratification act on the grounds of its alleged incompatibility with the German Basic Law. Representatives of these groups, Manfred Brunner, Karl Albrecht Schachtschneider, Hans-Christian Ströbele and Ulrich K. Preuß accused the government and parliament of agreeing to the transfer of German sovereignty to supranational bodies, which purportedly deprived the Bundestag of its power and was contrary to the principles of democracy. The transfer of powers to supranational organizations was allegedly a violation of the Basic Law, since decisions on such vital matters as sovereignty should be taken in Germany and not on the European level. Federal President Johannes Rau explained to the Federal Constitutional Court that he would only sign the ratification if the Court did not uphold the complaints (Bryde, 1993, p. 37).

It was not until October 12, 1993 that the Second Senate of the Federal Constitutional Court issued its long-awaited ruling on the Maastricht Treaty. Out of the five complaints referred to in the ruling, four did not pass the admissibility test and were dismissed. Only the complaint by Manfred Brunner, former Head of Cabinet of EC Commissioner Martin Bangemann, was declared formally admissible, but it was then rejected for lack of grounds (Winkelmann, 1994).

The activities of the Bundestag in the 1990s and in the early $21^{\text {st }}$ century had a huge impact on the development of German defense policy, and thus had a direct impact on the overall shape and effectiveness of the EU's Common Foreign and Security Policy and the Common Security and Defense Policy.

From 1993, Chancellor Kohl's government tried to push through a parliamentary law that would make it possible to amend the Basic Law and allow Bundeswehr soldiers to participate in international armed forces. However, those efforts came up against strong resistance from the opposing SPD, which did not accept the participation of German troops in any peace-making operations and only tolerated peace-keeping ones, as long as they were based on a specific UN mandate (Diehl, 1994, p. 445).

On July 12, 1994, the ruling of the Second Chamber of the Constitutional Court created a constitutional and legal basis for the use of the German armed forces abroad. The parties of the ruling CDU/CSU-FDP coalition, constantly under fire from their western allies, decided to increase the Bundeswehr's participation in peace-keeping operations in former Yugoslavia. Wolfgang Schäuble, head of the CDU/CSU parliamentary faction, was supposed to say publicly that "now we will certainly use more than just a checkbook." The Court's ruling finally put an end to speculations about the admissibility, competences and limits of Germany's active foreign and security policy. The Federal Republic was formally 'allowed' to fulfill the obligation guaranteed in the 
preamble to the Basic Law towards NATO and the European Union, i.e. "to promote world peace as an equal partner in a united Europe." The parliament's approval of such military operations was treated by the judges as a sine qua non condition for any political decision to deploy the Bundeswehr outside the scope of NATO operations (Urteil, 1994, p. 5).

The Court's verdict of July 12, 1994 allowed the Bundeswehr to participate in peacekeeping operations not only as part of peace missions of the Blue Helmets but also in NATO combat operations, provided that each time a decision in favor of such actions was taken by a simple majority of the Bundestag. This definitively put an end to the long-standing dispute in Germany over the constitutional and legal basis for the use of German armed forces outside Germany. The parties of the ruling CDU/CSUFDP coalition, accused of inaction and under fire from their western allies, decided to increase the Bundeswehr's participation in peacekeeping operations in former Yugoslavia (Balkan, 1994).

The assertive foreign and European policy of the Schröder/Fischer government (1998-2005), characterized by prioritizing German national interests, resulted in Berlin's refusal to participate in the anti-Iraq operation orchestrated and conducted by the United States in April 2003. As a result of the ensuing public debate, on March 18, 2005 the Bundestag adopted another Law on the Participation of the Parliament in Decisions on the Deployment of Armed Forces Abroad. Only those missions in which Bundeswehr soldiers would be involved in armed activities would require the Bundestag's consent. This did not apply to humanitarian, rescue and peace-keeping (policing) missions. The procedure required the Federal Government to send a request to the Bundestag for approval for the deployment of the armed forces, in good time before the start of the mission. It was specified that such a request should specify the task of the mission, its application, legal basis, the number of soldiers required, the possibility of using the armed forces, the planned duration of the mission and the estimated costs of the expedition of German soldiers (Gesetz über die parlamentarische Beteiligung, 2005).

The Bundestag's influence on European politics was most evident after the adoption of the Lisbon Treaty. After the end of the Portuguese Presidency, crowned by the signing of the Lisbon Treaty on December 13, 2007, the process of the Treaty's ratification by the European Parliament and the member states of the European Union began. On April 24, 2008 the Bundestag ratified the Lisbon Treaty in a landslide vote, as the coalition parties and most of the opposition voted in favor of the Lisbon Treaty. Angelica Schwall-Düren, Vice-Chairwoman of the SPD parliamentary group in the Bundestag, and Volker Kauder, head of the CDU/CSU group, were in favor of rapid ratification of the Treaty, saying that it "strengthened democracy" in the EU and made it more "specific." 515 MPs supported the ratification of the Treaty. 58 MPs from Die Linke (The Left) voted against, and its leader Lothar Bisky criticized the Lisbon Treaty as being a virtual copy of the rejected European Constitution. Die Linke was also in favor of holding a referendum on the Treaty's ratification (Bundestag ratifiziert EUReformvertrag, 2008).

The Bundesrat vote took place on May 23, 2008. The Lisbon Treaty was supported by 15 of the 16 Länder of Germany, with Klaus Wowereit, the mayor of Berlin (SPD), 
abstaining in the wake of Berlin SPD's conflict with its coalition partners (the postcommunist Left), who rejected the Lisbon Treaty, considering it a manifestation of "neoliberalism and militarism." Immediately after the vote, Peter Gauweiler, a Bavarian Christian Democrat politician (CSU), and Dieter Dehm, a left-wing MP, challenged the new treaty before the Constitutional Court in Karlsruhe, claiming that the document was undemocratic, threatened Germany's sovereignty and weakened the role of national parliaments. Mr. Dehm also spoke about "militarization of the European Union" following the adoption of CSDP-related provisions in the Treaty (Fahrun 2008; Volksabstimmung 2008) (Fahrun, 2008; Volksabstimmung, 2008).

Federal President Horst Köhler approved the content of the Lisbon Treaty, but, as previously announced, refrained from signing the instrument of ratification until the ruling of the Constitutional Court. The case became even more complicated in January 2009, when the Court received another complaint against the ratification of the Lisbon Treaty, submitted by Dieter Spethmann, a former management board member of Thyssen AG, Franz Ludwig Graf Stauffenberg, a former MEP from the CSU, Joachim Starbatty, a business expert, and Markus Kerber, a law professor from Berlin. They claimed that the government, by ratifying the Lisbon Treaty, would violate the Constitution, thus posing a threat to financial stability. In their opinion, the expectations of the Constitutional Court regarding European integration expressed in the 1993 judgment on the Maastricht Treaty (which consequently allowed the introduction of the euro) had proven false. The EU was in constant breach of the Stability and Growth Pact, the European Commission exceeded its mandate and the distribution of rights was not transparent (Wefing, 2009). Much to the dissatisfaction of Chancellor Merkel, the whole procedure was delayed because both complaints had to be dealt with separately.

On June 30, 2009, the Federal Constitutional Court in Karlsruhe ruled that the Lisbon Treaty was in keeping with the German Constitution. At the same time, it added that the role of the Bundestag and the Bundesrat in the European Union had to be strengthened. Referring to its earlier ruling of October 12, 1993 on the Maastricht Treaty, the Court stated that the European Union, while possessing a legal personality, remains a "union of states" (Staatenverbund), but is in no way a federation. According to this interpretation, the term "interlinked states" means "a close and lasting bond between sovereign states" (enge auf Dauer angelegte Verbindung souverän bleibende Staaten), which exercises public power on the basis of the treaties and whose system is determined solely by the EU member states. "The peoples" living in the member states remain the stakeholders in the process of democratic legitimization of the European Union. In the ruling of the Federal Constitutional Court, the European Union is no longer an "ordinary' "union of states" (Staatenverband), but it not yet a "federal state" (Bundesstaat). The EU does not have its own "state sovereignty" (souveräne Eigenstaatlichkeit), which only member states have. The Court pointed out that the European Union has only the authority allowed by its member states, by virtue of the treaties approved by national parliaments. The sovereignty of the member states is safeguarded, inter alia, by the principle of conferred powers. As aptly noted by Janusz J. Węc, a political scientist from Cracow, "member states continue to be 'the rulers of treaties' and the European Union has not acquired the competency to establish its own competencies" (Węc, 2011, p. 119). 
The Federal Constitutional Court stated that the European Union was a union of sovereign states, rather than a federation. If Germany wanted to become a part of a European federation, then - according to Article 146 of the German Constitution - the nation would have to decide on this in a referendum, after a new German constitution was created to allow it.

In a reassuring tone, the Constitutional Court explained that, although the Lisbon Treaty marks the beginning of a new phase of European integration, the Federal Republic would not lose its sovereignty after its entry into force and would continue to be an entity recognized by international law. The existing state system was guarded by the current Basic Law, which prevented the formation of a federation that the German people could join. If such a concept of a European federation were to emerge in the future, the German nation (sovereign) - as mentioned above - would have to express its will, and the German Constitution would have to be changed (ibid.).

In accordance with the Court's ruling, the Bundestag would, among other things, give its consent to the transfer of competencies to the EU in areas such as criminal law, defense policy, environmental protection, cross-border aspects of family law, labor law and social matters, as well as to the application of the so-called flexibility clause, which gives the EU the right to take action in areas not provided for in the Treaty ( $\mathrm{Ge}$ setz über die Wahrnehmung, 2009).

The judges expressed concerns that the ongoing process of giving additional competencies to EU bodies would reduce German sovereignty. Thus, as already mentioned, they indirectly stated that the creation of a federation of EU member states would be contrary to the German Basic Law. These issues were to be set forth in an amendment to the new Competencies Act at the end of August 2009, even before Bundestag elections. Until then, President Köhler was unable to sign the ratification act (Jungholt, 2009).

Not without some delay, on September 8, 2009, the Bundestag passed the Competencies Act. The new law, supported by all parties except the post-communist Left, strengthened the influence of the Bundestag and the Bundesrat in matters relating to the European Union.

The other member states were notified that Germany was bound by a judgment of the Constitutional Court on the new EU treaty. The measure also met the expectations of the Bavarian CSU, which demanded that the Bundestag adopt an additional resolution stating that the Lisbon Treaty would be applied in Germany in accordance with the Court's interpretation. However, the other parties did not support this proposal. The competencies laws accompanying the ratification of the Lisbon Treaty consisted of the following five Acts:

- Act Extending and Strengthening the Rights of the Bundestag and the Bundesrat in Matters Concerning the European Union (Gesetz über die Ausweitung und Stärkung der Rechte des Bundestages und des Bundesrates in Angelegenheiten der Europäischen Union);

- new Act on the Responsibility for Integration (Gesetz über die Wahrnehmung der Integrationsverantwortung des Bundestages und des Bundesrates in Angelegenheiten der Europäischen Union);

- Act Amending the Basic Law on the Ratification of the Lisbon Treaty (Gesetz zur Umsetzung der Grundgesetzänderungen für die Ratifizierung des Vertrags von Lissabon); 
- Act Amending the Act on Cooperation between the Federal Government and the Bundestag in EU matters (Gesetz über die Zusammenarbeit von Bundesregierung und Deutschem Bundestag in Angelegenheiten der Europäischen Union);

- Act Amending the Act on Cooperation between the Federation and the Länder on European Union Matters (Gesetz über die Zusammenarbeit von Bund und Ländern in Angelegenheiten der Europäischen Union). ${ }^{3}$

Although 446 MPs voted in favor of the laws and only 46 MPs, mainly from the Die Linke party, were against it, it was not all as harmonious as it might appear at first glance. CSU leader Horst Seehofer unexpectedly submitted a list of 14 demands and objections. Among other things, he demanded national referendums on "important European issues" that would be binding on the government. He also demanded the monitoring of European law by the German Constitutional Court. After the adoption of the laws by the Bundestag, the Bundesrat approved them on September 18, following which they were finally signed by President Horst Köhler (bart, 2009).

The adopted laws significantly strengthened the influence of the German Parliament over the European policy of the government. For instance, the Bundestag was to be notified quickly and comprehensively by the Cabinet of the EU's decisions. The notification should include information on the position of the Federal Government, preparations for and conduct of discussions in the EU's institutions, comments by the European Parliament, the European Commission and other EU member states and the decisions taken. This was also to apply to all preparatory committees and working groups. The obligation to provide information also applies to the preparation and proceedings of informal meetings of ministers of the euro summit, the Eurogroup and similar institutions (Gesetz über die Zusammenarbeit, 2013). The parliament's consent was necessary in the event of transferring federal competencies in certain areas to the EU institutions. The newly adopted laws did not only confer veto rights to the Bundestag, but the German government also undertook to keep the parliament fully informed about the plans and intentions of its European policy. In addition, the Bundestag had to authorize the opening of negotiations with new membership candidates and the negotiation of new treaties. The Bundestag gained the power to order the government to bring an action before the Court of Justice of the European Union if it transpired that the Union was interfering with Germany's internal affairs. The law on responsibility for integration provided for two types of cooperation right; first, it specified the right of participation, which the Federal Constitutional Court formulated pursuant to the Basic Law according to the principle of 'responsibility for integration.' In addition, the law changed the rights of national parliaments resulting from the Lisbon Treaty, which had a direct impact at the European level. Regulations such as, for example, the right to

${ }^{3}$ Gesetz über die Ausweitung und Stärkung der Rechte des Bundestages und des Bundesrates in Angelegenheiten der Europäischen Union vom 22.09.2009, https://www.buzer.de/gesetz/9032/ index.htm; Gesetz über die Wahrnehmung; Gesetz zur Umsetzung der Grundgesetzänderungen für die Ratifizierung des Vertrags von Lissabon vom 1.Dezember 2009, dipbt.bundestag.de/doc/ btd/16/139/1613924.pdf; Gesetz über die Zusammenarbeit von Bundesregierung und Deutschem Bundestag in Angelegenheiten der Europäischen Union, Bundestministerium der Juztiz und für Verbraucherschutz, 4.07.2013, http://www.gesetze-im-internet.de/euzbbg_2013/BJNR217000013. $\mathrm{html}$; Gesetz über die Zusammenarbeit von Bund und Ländern in Angelegenheiten der Europäischen Union vom 23.03 1993, https://www.gesetze-im-internet.de/euzblg/BJNR031300993.html. 
complain about compliance with the principle of subsidiarity, were already included in the old law and were carried over from it. Another important issue were the so-called 'bridging clauses,' which make it possible to change the voting method in the Council of the European Union (qualified majority). Importantly, although the change makes it easier to reach a final solution, it also weakens the positions of individual member states, which may be outvoted. Therefore, the Lisbon Treaty introduced safeguards for the parliaments of the member states: if the European Council decides to take an initiative, the parliaments of the member states are informed thereof. They may veto this initiative (without the government's involvement) directly at the European level within six months. If there is no such veto, the European Parliament must give its consent. The final decision must then be taken by the Council of the EU. A voice from the Bundestag could once again be heard at this stage: the German representative in the Council can only vote in favor of this proposal after the entry into force of the relevant federal law. According to the intention of the Federal Constitutional Court, this could be seen as a so-called double guarantee (Der Lissabon-Vertrag stärkt die Parlamente, 2013).

The German Parliament played an important role during the financial crisis in the euro zone, when it joined the efforts to support Greece, which found itself at the brink of financial collapse. On April 23, 2010, the government in Athens officially asked the European Union and the International Monetary Fund (IMF) for financial assistance. On May 2, the Finance Ministers of the eurozone agreed on a rescue package for Greece, worth EUR 110bn over the next three years, subject to severe budget cuts. The IMF's share in the relief effort was in the area of EUR 30bn.

On April 27, the German Finance Ministry submitted a special draft law to the parliament. On May 7, 2010, Chancellor Merkel presented a draft aid plan for Greece to Members of the Bundestag and announced that Germany's participation would be EUR 22.4bn, in the form of loans and loan guarantees. In her opinion, the Greek government's promise to implement radical austerity measures to reduce the budget deficit would allow the aid plan to be implemented. The Chancellor patiently explained that no important decision could be taken in the European Union without Germany or against Germany. She said that financial assistance could not have been provided to Greece earlier because it could have been counterproductive. The implementation of the rescue package for Greece was only possible when Greece explained how it intended to reduce its excessive budget deficit and internal debt. The act authorizing the government to participate in the rescue plan was passed by the Bundestag after the first reading (Gesetz zur Übernahme von Gewährleistungen, 2010).

On May 19, another draft on the government's financial guarantees under the European Financial Mechanism was fast-tracked to the Bundestag. On May 22, it was approved by the Bundesrat and signed by President Horst Köhler, as one of the last documents signed by him in that capacity. The law stipulated that emergency measures requested by a eurozone member could be "used to maintain solvency if absolutely necessary in order to safeguard the stability of the eurozone as a whole." The granting of these "emergency measures" was to be subject to "strict conditions" set by the IMF, the ECB, the European Commission and the country concerned (Gesetz zur Übernahme von Gewährleistungen im Rahmen eines europäischen Stabilisierungsmechanismus, 2010). 
After receiving the consent of the German Parliament, a coordinated action by the eurozone countries and the IMF was launched, eventually resulting in disbursing further tranches of financial assistance to Greece from the huge financial package of EUR 110bn. The money was primarily intended to support Greece's domestic banks, stabilize the budget and halt the economic downturn. However, it soon became clear that the catastrophic collapse of the Greek economy and social resistance to drastic austerity reforms would require another aid package for the country. The European Commission considered it necessary to prepare a second aid package for Greece with the active involvement of the European Central Bank. The aid was to be conditional on the continuation of austerity measures by the Greek government. In addition, the reforms had to be agreed upon with major political parties in Greece, including, first and foremost, the conservative opposition and the socialists (Griechenland-Hilfe, 2011).

During a fierce debate in the Bundestag on September 7, 2011, Chancellor Merkel made a dramatic appeal for more financial support ("if the euro fails, Europe fails") for countries at risk. She announced internal austerity and attacked the former SPD/Green government, which was unable to reform public finances and, despite the critical opinions of many experts, agreed that Greece should join the eurozone. In response, the Social Democrats accused her of conducting a chaotic foreign policy and delaying the green light to help Greece because she did not want to upset voters before important parliamentary elections in the Länder (Generaldebatte im Bundestag, 2011).

Before the vote in the Bundestag at the end of September 2011, which was so important for Merkel's cabinet, Germany stepped up pressure on Greece to resolutely continue repairing the state's finances, as this would determine the flow of money to its economy from aid funds. Despite an open rebellion, even within the CDU and CSU, the Chancellor knew well that coalition loyalty would stay strong, as the alternative would mean the collapse of her government and early elections. She was also aware that in this matter she could count on the pro-European opposition (SPD), who supported the plans to save Greece from financial collapse. Under such circumstances, the results of the Bundestag vote on September 29, 2011 were a foregone conclusion. The European Financial Stability Facility (EFSF) was supported by an overwhelming majority. A total of 523 members of the Bundestag voted in its favor, 85 were against, and three abstained (Entwurf eines Gesetzes, 2011; Bannas, 2011).

Another decision of the Bundestag connected with various ideas on how to solve the eurozone crisis concerned the creation of special financial instruments that could be used to support countries at risk or to prevent a crisis situation from happening again. By a decision of the European Council of March 25, 2011, the two temporary European stability mechanisms (EFSF and EFSM) were replaced in the second half of 2012 with a permanent financial assistance mechanism for eurozone countries - the European Stability Mechanism (ESM). The role of this permanent mechanism, managing a huge budget of EUR 700bn, was to disburse funding and provide assistance to eurozone countries at risk, based on strict conditions. The ESM provided a permanent crisis resolution framework to safeguard the overall financial stability of the eurozone. The ESM took over the responsibilities of the temporary mechanisms (EFSF and EFSM) and complemented the EU's new enhanced economic surveillance framework. 
The ESM was established by agreement between the eurozone member states as an intergovernmental organization under public international law based in Luxembourg. It required ratification by all eurozone countries. In the case of Germany, the granting of loans and German participation in the ESM required the statutory approval of the Bundestag.

The ratification of the fiscal pact and the ESM by Germany on June 29, 2012 in the Bundestag was not the last step in the legislative process, as it did not take effect due to a complaint submitted to the Constitutional Court. The complaining party asked the Court to examine the compatibility of the euro rescue packages with the German Basic Law. At the Court's request, President Joachim Gauck did not sign the law. Karl Albrecht Schachtschneider, a law professor and constitutionalist from Nuremberg, Joachim Starbatty, an economist from Tübingen, Wilhelm Nölling, a former Senator from Hamburg, Wilhelm Hankel, an 82-year-old economist, and Dieter Spethmann, the former CEO of Thyssen, believed that the government's decision to participate in the ESM would increase Germany's already record debt and trigger inflation. Christoph Degenhart, a state law specialist from Nuremberg, and Herta Däubler-Gmelin (SPD), a former German Minister of Justice, questioned both rescue packages for Greece, claiming that the EU's anti-crisis ESM and the so-called fiscal pact, adopted on the initiative of Germany, violated democratic principles, both at the European level and within Germany itself. Degenhardt and Däubler-Gmelin, together with a total of 37,000 citizens, supported the claims submitted to the Constitutional Court. 25,000 citizens directly joined the constitutional complaint of More Democracy, an association founded by Degenhardt and Däubler-Gmelin. In addition, complaints against the European Stability Mechanism were submitted by the parliamentary club of the Die Linke Party and, as one might expect, the Bavarian CSU politician Peter Gauweiler (Niemcy: czekanie na wyrok Trybunatu Konstytucyjnego, 2012).

Critics argued that the ESM Agreement did not have a termination and limitation of liability clause. Theoretically, the Council of Finance Ministers of the eurozone can increase the total subscribed capital of the ESM as and when needed, and thus increase the guarantees provided by the states. This would violate the sovereign budgetary powers of the German Parliament and the provisions of the EU Treaty. According to the Treaty, member states are not liable for the obligations of other states (so-called no bail-out clause).

In the judgment of September 12, 2012, the Federal Constitutional Court did not find the law ratifying the international agreement on the permanent euro stability mechanism (ESM) to be in any way incompatible with the German Basic Law. However, certain conditions were prescribed by the Court. The judges indicated in their ruling that the amount guaranteed by Germany must not exceed EUR 190bn, and, if this were to be exceeded, the consent of the Bundestag was necessary (Beschwerde zurückgewiesen, 2012; Euro-Urteil, 2012).

The decision of the Court of Justice was welcomed with relief by the German government. Chancellor Merkel spoke of "a good day for Germany and Europe." As a result, on September 28, the Bundestag passed a law on Germany's participation in the ESM with a total financial contribution of EUR 189,994bn, of which nearly 170 billion were loan guarantees (Gesetz zur finanziellen Beteiligung, 2012). 
Since it was financial institutions that sparked the crisis situation in the eurozone, a solution to prevent such crises from reoccurring was the Banking Union. According to a report by Herman van Rompuy, President of the European Council, adopted at the European Council meeting in December 2012, steps were taken to make the Banking Union a reality. It was to be based on three pillars: a single supervisory mechanism, a single resolution mechanism, and interconnected financing mechanisms (common to the whole internal market), i.e. a single resolution fund, deposit guarantee scheme, and common system for deposit protection (credit line) (Węc, 2014, pp. 33-34).

On November 6, 2014, the proposal was discussed in the Bundestag, as the government submitted four bills intended to enable and support the Banking Union. In recommending them to Bundestag members, Finance Minister Wolfgang Schäuble hailed the Banking Union as "the biggest integration project since the introduction of the euro and an important element of financial governance in Europe." Despite the protests on the left, the four laws were adopted by an overwhelming majority (Deutscher Bundestag beschließt vier Gesetze, 2014).

Out of the 23 Committees in the 18th Bundestag (2013), the European Union Affairs Committee (Der Ausschuss für die Angelegenheiten der Europäischen Union), set forth in the German Basic Law, played a key role in Germany's European policy issues. The European Union Affairs Committee is one of the four committees (the other three being the Defense Committee, the Foreign Affairs Committee and the Petitions Committee) explicitly mentioned in the Basic Law (Art. 45) and must be set up in each legislative period. The Committee, in the capacity of an Integration and Intersectionality Board, participates in the most important decisions, without prejudice to the competencies of the other committees in charge of specific topics. In principle, all committees of the German Bundestag are responsible for advising on European matters within their respective areas of competence. However, as an integration and intersectionality board, the EU Affairs Committee is a central part of Germany's decisionmaking process on European issues. In this capacity, it is responsible for fundamental issues of European integration, institutional reforms, EU enlargement and cooperation with the European Parliament and the national parliaments of the other member states. As a horizontal committee, it deals in particular with European projects covering several different policy areas. It participates in the process of setting up EU agencies and multi-annual programs such as Europe 2020 or the 2009 Stockholm Program (Ausschuss für die Angelegenheiten, 2013).

Until the first direct elections to the European Parliament in 1979, parliamentarians from the European Community were elected by national parliaments. In Germany, Members of the European Parliament were also members of the German Bundestag. After 1979, these double mandates expired and the Bundestag was no longer well informed on EC matters. In response, the committee of the so-called Elders' Councils proposed some improvements. In 1983, the 10th Bundestag set up a European Committee, featuring 11 parliamentarians and 11 MEPs. Nevertheless, still too few people were formally involved in these structures. In 1991, the 12th Bundestag established the European Community Affairs Committee, which focused on the creation of the European Union (Maastricht Treaty) and, in particular, on the economic and monetary union (Abels, 2015 p. 117). 33 members of the Bundestag and 11 MEPs joined the Committee. However, 
being a horizontal committee, it was not entitled to submit decision proposals, as this remained the domain of the relevant specialist committees. It was not until 1994, at the time of the 13th Bundestag, that today's EU Committee was established and given special powers (Bundestag und Europa Europäische Union, 2007, pp. 4-5).

The Federal Government is legally obliged to comprehensively and promptly inform the Bundestag about all projects that may be of interest to the Federal Republic of Germany within the European Union. This is done through written and oral reports from meetings of the European Council and the Council of the European Union in its various configurations. In addition, briefings are held on current initiatives and events at the European level, in which the position of the Federal Government is explained (Aufgaben und Arbeit).

The Committee regularly invites European institutions (members of the European Commission, representatives of other member states, Members of the European Parliament, directors of EU agencies and experts) in order to stay up to date with current developments in the EU. The EU Affairs Committee is also responsible for liaising with the European Parliament and the parliaments of the other EU member states and candidate countries, and participates in meetings of the Conference of Community and European Affairs Committees of Parliaments of the European Union (COSAC).

As a rule, the Committee does not deal with the implementation of directives already adopted at the EU level, as this is the responsibility of the relevant specialist committees. The EU Affairs Committee, like the other committees of the German Bundestag, is responsible for preparing decisions taken at plenary sessions. Under certain conditions, the Committee can implement the laws of the German Bundestag and make statements to the Federal Government (so-called Plenary Resolutions). In this way, it can, if necessary, clarify on a case-by-case basis the parliament's position on legislative proposals of the European Union. Unlike other committees, the EU Affairs Committee can propose amendments to the recommendations of other committees.

The 34 members of the Committee established by the 18th Bundestag included 17 CDU/CSU members, 11 SPD members and 3 members from Die Linke and from Bündnis 90/Die Grünen. In addition, the EU Affairs Committee features 15 German MEPs, who are non-voting members of the Committee. By participating in the Committee, the MEPs ensure cooperation at the national and European level. The Committee was chaired by Gunther Krichbaum, a member of the CDU and a lawyer, who had held this office since 2007, and entered the Bundestag in the 2017 elections with a direct mandate.

\section{Bibliography}

Abels G. (2015), Die Rolle des Bundestages in der deutschen Europapolitik aus politologischer Perspektive, http://iep-berlin.de/wp-content/uploads/2017/08/10_Bundestag_Abels_MJ.pdf.

Aufgaben und Arbeit des Ausschusses für die Angelegenheiten der Europäischen Union, https:// www. bundestag. de/ ausschuesse/ausschuesse18/a21/aufgaben_und_arbeit.

Ausschuss für die Angelegenheiten der Europäischen Union (2013), https://www.bundestag.de/eu. content/uploads/2017/08/10_Bundestag_Abels_MJ.pdf $+\& \mathrm{~cd}=5 \& \mathrm{hl}=\mathrm{pl} \& \mathrm{ct}=\mathrm{clnk} \& \mathrm{gl}=\mathrm{pl} \& \mathrm{cli}-$ ent=firefox-b-ab. 
Balkan in Bonn (1994), "Der Spiegel” April 18.

Bannas G. (2011), Mehr als eine Mehrheit, "Frankfurter Allgemeine Zeitung” Sept. 30.

bart (2009), Niemcy zrobily krok bliżej Lizbony, “Gazeta Wyborcza” Sept. 8.

Beschwerde zurückgewiesen: Bundesverfassungsgericht billigt EU-Rettungsschirm (2012), "Frankfurter Allgemeine Zeitung" Sept. 7.

Bundestag und Europa Europäische Union und Europapolitik im Parlament (2007), Berlin.

Bundestag ratifiziert EU-Reformvertrag (2008), http://www.deutschlandradio.de/bundestag-ratifiziert-eu-reformvertrag.331.de.html?dram:article_id=202063.

Bryde B.-O. (1993), Das Maastricht-Urteil des Bundesverfassungsgerichts. Konsequenzen für die weitere Entwicklung der europäischen Integration, Tübingen Universität Verlag.

Diehl O. (1994), UN-Einsätze de Bundeswehr. Aussenpolitische Handlungszwänge und innenpolitischer Konsensusbedarf, "Europa-Archiv," issue 9.

Deutscher Bundestag beschließt vier Gesetze zur Umsetzung der Europäischen Bankenunion, Bundesministerium der Finanzen, http://www.bundesfinanzministerium.deContent/DE/ Video/2014/ 2014-11-06-bundestag-bankenunion/2014-11-06-bundestag-bankenunion.html.

Entwurf eines Gesetzes zur Änderung des Gesetzes zur Übernahme von Gewährleistungen im Rahmen des europäischen Stabilisierungsmechanismus, 28.09.2011, http://dipbt.bundestag.de/ $\operatorname{dip} 21 /$ btd/17/069/1706916.pdf.

Euro-Urteil: Richter retten Euro-Retter (2012), "Financial Times Deutschland" Sept. 7.

Fahrun J. (2008), Bundesrat: Die rot-rote Koalition pokert um den EU-Vertrag, "Die Welt" May 22.

Generaldebatte im Bundestag: ,, Scheitert der Euro, scheitert Europa” (2011), "Frankfurter Allgemeine Zeitung" Sept. 7.

Gesetz über die parlamentarische Beteiligung bei der Entscheidung über den Einsatz bewaffneter Streitkräfte im Ausland (2005), Deutscher Bundestag, https://www.bundestag.de/bundestag/ aufgaben/rechtsgrundlagen/parlamentsbeteiligung.

Gesetz über die Wahrnehmung der Integrationsverantwortung des Bundestages und des Bundesrates in Angelegenheiten der Europäischen Union, Bundestministerium der Juztiz und für Verbraucherschutz, 22.09.2009, http://www.gesetze-im-internet.de/intvg/BJNR302210009.html.

Gesetz über die Zusammenarbeit von Bundesregierung und Deutschem Bundestag in Angelegenheiten der Europäischen Union, Bundestministerium der Juztiz und für Verbraucherschutz, 4.07.2013, http://www.gesetze-im-internet.de/euzbbg_2013/BJNR 217000013.html.

Gesetz zur Übernahme von Gewährleistungen zum Erhalt der für die Finanzstabilität in der Währungsunion erforderlichen Zahlungsfähigkeit der Hellenischen Republik, 7.05.2010, https:// www.gesetze-im-internet.de/wfstg/BJNR053700010.html.

Gesetz zur finanziellen Beteiligung am Europäischen Stabilitätsmechanismus (ESM), 13.09.2012, http://www.gesetze-im-internet.de/esmfing/BJNR191800012.html.

Griechenland-Hilfe: Merkel und Sarkozy wollen Privatsektor beteiligen (2011), "Die Welt" June 17.

Jungholt T. (2009), Urteil zum Reformvertrag: Karlsruhe hat der EU deutliche Grenzen gesetzt, "Die Welt" July 30.

Niemcy: czekanie na wyrok Trybunału Konstytucyjnego ws. ratowania strefy euro (2012), "Deutsche Welle," Sept. 11, http://www.dw.com/pl/niemcy-czekanie-na-wyrok-trybuna\%C5\%82ukonstytucyjnego-ws-ratowania-strefy-euro/a-16231088.

Suszycka-Jasch M., Jasch H.-D. (2009), The parcipation of the German Laender in formulating German EU-policy, "German Law Journal”, vol. 10.

Traktat z Lizbony zmieniający Traktat o Unii Europejskiej i Traktat ustanawiający Wspólnotę Europejska (2009), Dz. U. Nr 203. 
Urteil des Bundesverfassungsgerichts vom 12. Juli 1994 (1994), Karlsruhe.

Ustawa Zasadnicza Republiki Federalnej Niemiec (2007), stan prawny na 30 czerwca 2007 r., Wyd. Instytutu Zachodniego, Poznań.

Volksabstimmung in Deutschland über den Vertrag von Lissabon? (2008), Deutscher Bundestag. Wissenschaftliche Dienste, https://www. bundestag.de/blob/../wd-3-135-09-pdf-data.pdf.

Wefing H. (2009), Lissabon-Vertrag: Verfassungsgericht lässt Skepsis erkennen, "Die Zeit” Feb. 10.

Węc J. J. (2011), Traktat lizboński. Polityczne aspekty reformy ustrojowej Unii Europejskiej w latach 2007-2009, Księgarnia Akademicka, Kraków.

Węc J. J. (2014), Proces konstytuowania Unii Bankowej. Geneza, podstawy prawne, cele i zasady działania, "Rocznik Integracji Europejskiej," issue 8.

Winkelmann I. (Hg.) (1994), Das Maastricht-Urteil des Bundesverfassungsgerichts vom 12. Oktober 1993. Dokumentation des Verfahrens mit Einführung, Duncker und Humblot Verlag, Berlin.

\section{Summary}

Pursuant to the German constitution, the Bundestag exercises parliamentary control over the government's European policy. In its activities in the European Union the government must take account of the Bundestag's proposals. The 2009 Competencies Laws strengthened the parliament's position in European government policy, making any major decision on EU matters practically dependent on the consent of the Bundestag. According to the author, although this severely restricted Chancellor Merkel's freedom of action, it did not paralyze the government's European initiatives. The German Parliament behaved responsibly, especially during the financial crisis in the eurozone, allowing financial support for Greece, the establishment of the European Stability Mechanism and the establishment of the Banking Union.

Key words: united Germany, Bundestag, European politics

\section{Rola Bundestagu w ksztaltowaniu polityki europejskiej zjednoczonych Niemiec}

\section{Streszczenie}

Zgodnie z Ustawą zasadniczą Niemiec, to Bundestag sprawuje parlamentarną kontrolę nad europejską polityką Niemiec. Każdorazowo rząd musi informować o swoich zamierzeniach posłów. Ustawy kompetencyjne z 2009 r. wzmocniły dodatkowo parlamentarną kontrolę, uzależniając podjęcie każdej kluczowej dla losów Niemiec decyzji w Unii Europejskiej od zgody deputowanych. W opinii autora ogranicza to możliwości do działania rządu Merkel w UE, ale też nie paraliżuje jego inicjatyw. Bundestag zachowywał się odpowiedzialnie i zgodnie z wolą rządu w okresie kryzysu finansowego strefy euro, gdzie wymagana była zgoda na finansową pomoc dla Grecji, ustanowienie Europejskiego Mechanizmu Stabilności i unię bankową.

Słowa kluczowe: zjednoczone Niemcy, Bundestag, polityka europejska 
